\title{
Space agency reform plans under scrutiny
}

Paris. France's Centre National d'Etudes Spatiales (CNES), the world's third biggest space agency and the driving force behind Europe's space programme, is on the verge of a major reorganization aimed at adapting to the new environment created by the end of the Cold War and the increasing commercialization of space activities.

But many observers have been disappointed by a draft of the agency's strategic plan for 1996 to 2006, which was presented last week at a large gathering of space administrators, industrialists and researchers in Paris. Critics claim that apart from the Ariane-5 programme - which is recognized as an "absolute priority" by CNES, the French government, and the European Space Agency (ESA) - the plan makes few distinctions as to the weight that needs to be given to CNES's various activities.

"Everything seems to be a priority [in the strategic plan]," says Mark Giget, head of the Paris-based space consultancy, Euroconsult. The plan "is very vague", adds one leading science administrator.

According to the critics, these failings suggest that CNES still has far to go before adapting to the painful changes demanded by the new political and economic climate. Francois Fillon, the French space minister, left delegates at last week's meeting in no doubt that the government wants to see CNES make such changes.

One reason the space agency is having difficulty in adapting is that it is only beginning to recover from a long-running internal crisis over its aims. One observer says this came to a head last year following the decision by Europe's space ministers at a meeting in Toulouse to agree on the participation of ESA in the international space station.

CNES has paid a heavy price for the agreement reached, and will need to make economies of 5 per cent a year over the period 1996 to 2000 to pay for its contribution to the station programme. Investment in domestic programmes is likely to stagnate as a result.

The consultation carried out as part of the preparation of the strategic plan by Alain Bensoussan, CNES's new president, was a "psychoanalytical" exercise aimed at "remobilizing and convincing staff that CNES must adapt" to the new conditions imposed by the Toulouse agreements, says one observer.

Indeed, CNES is suffering from an identity crisis, according to observers, that stems from the agency having become a victim of its own success. It was created in 1961 to allow France to compete with the two superpowers, by laying the foundations of a French space industry.

But the industries that CNES helped create have matured, while the need to compete with the United States is prompting a spate of mergers between French aerospace companies and those in other ESA member states, leading to a slow but inevitable Europeanization of French and other national space industries. Fillon said France, with its large domestic industrial base in aerospace, should become the "pivot" of the inevitable consolidation of Europe's space industry.

This marks a shift in French policy, away from driving Europe's efforts in space via the CNES, towards achieving this by flexing competitive industrial muscle. Fillon made it clear last week that the government wants CNES - which currently operates 18 industrial subsidiaries in areas from Earth observation to telecommunications - to withdraw from direct support for mature space technologies.

More and more of the work once done by space agencies is now being carried out by

\section{Bids open for supercomputing centres}

Washington. The US Department of Energy is seeking bids from multidisciplinary teams in US universities eventually to host up to five centres that will help to develop supercomputer applications to support its nuclear weapons programme. But department officials deny reports that they are preparing to spend up to $\$ 100$ million a year in the near future on university research related to the weapons programme.

Universities will be asked this week to submit proposals to host one of three or four supercomputer centres that will be established during 1997 under the energy department's Advanced Strategic Computing Initiative (ASCl), a giant programme to simulate nuclear weapons in the absence of testing. Dick Watson of the Lawrence Livermore National Laboratory in California says that the centres will have a joint budget of $\$ 5$ million in the first year, and that this will grow steadily to $\$ 25$ million five years from now.

According to Watson, the department also plans to spend between $\$ 3$ million and $\$ 4$ million a year on individual investigator research at the universities to support $\mathrm{ASCl}$, and is considering widening university involvement in the weapons programme. But he dismisses as "absolutely crazy" a report last week that the weapons programme would spend up to $\$ 100$ million next year with the universities. commercial companies. Fillon predicted that while the budgets of the world's space agencies would reach ECU150 billion (US $\$ 119$ billion) by the end of the century, the global space market would reach ECU360 billion.

"CNES needs to recentre its activities on long-term research and development," says Jean-Yves Le Gall, who is responsible for CNES's strategic plan. One longstanding

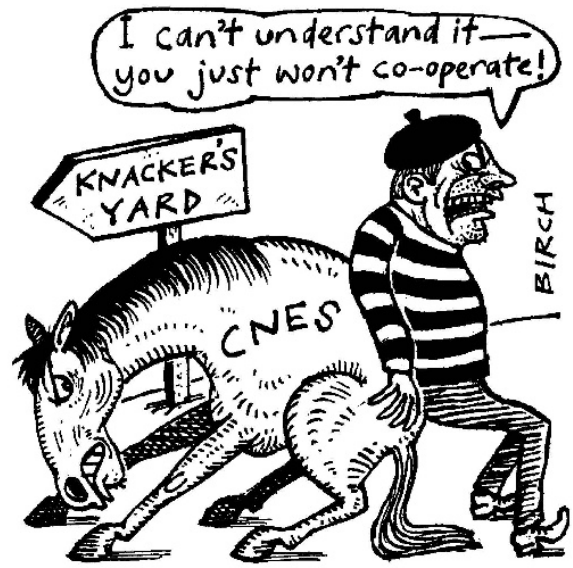

criticism of CNES is its relatively low spending on "advanced concepts" research such as robotics and artificial intelligence. "The job of CNES should be to identify technologies and develop advanced techniques" says one observer, adding that "industrial development should be left to industry".

Complicating matters further, the traditional role of space agencies in developing technologies is itself changing. One trend identified at last week's meeting was that technological innovations are increasingly originating from other sectors, such as computing, and the challenge for space agencies is now often to adapt these to the needs of space missions, as well as developing technologies from scratch.

CNES also faces an identity crisis in meeting the government's stated aim of making technological research and development more European. A European approach will become more and more important, said Fillon, arguing that this is essential if Europe is to build the critical mass needed to be a credible partner for the United States, Russia and Japan.

International collaboration will be the rule from now on, said Fillon, adding that European space policy needed to abandon its tradition of developing ambitious plans for an independent space programme. The Toulouse agreements had "modified the very sense of European space policy".

Fillon himself predicted last week that Europe's national space agencies would eventually be forced to rationalize their activities and become more European, although he admitted this would take a long time to come about.

Declan Butler 